\title{
ANALISIS TINGKAT KESEHATAN BANK PAPUA MENGGUNAKAN \\ METODE RBBR (RISK BASED BANK RATING) \\ PERIODE TAHUN 2011-2018
}

\author{
Eka Putri Innayah \\ IAIN Fattahul Muluk Papua \\ innayahekaputri77@gmail.com
}

\author{
Moh. Wahib \\ IAIN Fattahul Muluk Papua \\ wahibstainjaya@gmail.com \\ Ira Eka Pratiwi \\ IAIN Fattahul Muluk Papua \\ pratiwi.iraeka@khu.ac.kr
}

\begin{abstract}
This research aims to analyze the health level of Bank Papua for the period of 20112018 using the RBBR (Risk Based Bank Rating) method. In this study an assessment of three RBBR factors was cariied out, namely the risk profile factor through the NPL and LDR ratio, the profitability factor through the ROA and NIM ratio and capital factor through the CAR ratio. This type of research is descriptive with a quantitative approach. The formulation of the problem is twofold, firstly regarding the analysis of Bank Papua's soundness using the RBBR (Risk Based Bank Rating) method and the second concerns the performance of Bank Papua in terms of NPL, LDR, ROA, Nim and CAR indicators.

The results of this study indicate that based on the analysis of Bank Papua's soundness using the Risk Based Bank Rating (RBBR) method through NPL, LDR, ROA, NIM and CAR ratios, the condition of Banks Papua's soundness is categorized as being in a healthy predicate. However, the development of the ratio values in the 2011-2018 Papuan Banks each year moves fluctuatively, which means that their development fluctuates and in certain years can reach unfavorable figures on exceed the minimum threshold value of each ratio. Then based on NPL, LDR, ROA, NIM and CAR indicators, the Performance of the Papuan Banks in the 2011-2018 period is categorized as good. The conclusion of this research is based on the analysis or the soundness of the bank using the Risk Based Bank Rating (RBRR) method through the ratio of NPL, LDR, ROA, NIM and CAR, the condition of the health level of Bank Papua that can be categorized as being in a healthy predicate. Thean based on NPL, LDR, ROA, NIM and CAR, it can be concluded that the performance of Bank Papua is categorized as good.
\end{abstract}

Keywords: Banks Soundness, Risk Based Bank Rating (RBBR) method 


\begin{abstract}
ABSTRAK
Penelitian ini bertujuan untuk menganalisis tingkat kesehatan Bank Papua periode tahun 2011-2018 menggunakan metode RBBR (Risk Based Bank Rating). Dalam penelitian ini dilakukan penilaian terhadap tiga faktor RBBR, yaitu faktor Risk Profile melalui rasio NPL dan LDR, faktor rentabilitas melalui rasio ROA dan NIM dan faktor permodalan melalui rasio CAR. Jenis penelitian ini adalah deskriptif dengan pendekatan kuantitatif. Rumusan masalah ada dua, yaitu, pertama mengenai analisis tingkat kesehatan Bank Papua menggunakan metode RBBR (Risk Based Bank Rating) dan yang kedua menyangkut performa Bank papua dilihat dari indikator NPL, LDR, ROA, NIM dan CAR.

Hasil penelitian ini menunjukkan berdasarkan analisis tingkat kesehatan Bank Papua menggunakan metode Risk Based Bank Rating (RBBR) melalui rasio NPL, LDR, ROA, NIM dan CAR maka kondisi tingkat kesehatan Bank Papua yaitu dapat dikategorikan berada pada predikat Sehat. Namun demikian, perkembangan nilai-nilai rasio pada Bank Papua periode 2011-2018 setiap tahunnya bergerak secara fluktuatif yang berarti perkembangannya naik turun dan pada tahun-tahun tertentu bisa mencapai angka yang kurang baik atau melebihi batas minimum nilai dari masing-masing rasio. Lalu kemudian berdasarkan indikator NPL, LDR, ROA, NIM dan CAR performa Bank Papua dikategorikan baik. Kesimpulan dari hasil penelitian ini berdasarkan analisis tingkat kesehatan Bank Papua menggunakan metode Risk Based Bank Rating (RBBR) melalui rasio NPL, LDR, ROA, NIM dan CAR maka kondisi tingkat kesehatan Bank Papua yaitu dapat dikategorikan berada pada predikat Sehat. Kemudian berdasarkan indikator NPL, LDR, ROA, NIM dan CAR maka dapat disimpulkan bahwa performa Bank Papua dikategorikan baik.
\end{abstract}

Kata Kunci : Tingkat Kesehatan Bank, metode Risk Based Bank Rating (RBBR

\title{
PENDAHULUAN
}

Perbankan adalah segala sesuatu yang menyangkut tentang bank, mencakup kelembagaan, kegiatan usaha, serta cara dan proses dalam melaksanakan kegiatan usahanya. Bank merupakan jembatan alternatif yang memudahkan segala aktivitas masyarakat untuk menyimpan uang, dalam hal perniagaan, maupun untuk investasi masa depan.

Kesehatan bank adalah suatu kemampuan dimana bank mampu untuk melakukan kegiatan operasional perbankan secara normal dan dapat dengan mampu memenuhi kewajiban dengan baik dengan cara-cara yang sesuai peraturan perbankan yang berlaku (Totok dan Sigit, 2006). Hasil akhir penilaian kesehatan bank dapat dijadikan sebagai salah satu aspek dalam menetapkan strategi usaha di masa yang mendatang, sedangkan bagi Bank Indonesia diantaranya digunakan untuk salah satu dasar penetapan dan implementasi strategi pengawasan bank oleh Bank Indonesia. Di samping itu perkembangan industri perbankan, terutama produk dan jasa yang semakin kompleks dan beragam juga akan meningkatkan tingkat risiko yang dihadapi bank. Penilaian tingkat kesehatan bank merupakan penilaian kualitatif atas berbagai aspek yang berpengaruh terhadap kondisi atau kinerja suatu bank melalui penilaian aspek permodalan, tingkat kualitas aset, kesesuaian manajemen bank dalam praktiknya, rentabilitas, likuiditas dan sensitivitas terhadap resiko pasar. Penilaian terhadap faktor-faktor yang disebutkan itu dilakukan melalui penilaian kuantitatif dan kualitatif setelah mempertimbangkan unsur judgement yang didasarkan atas materialitas dan signifikansi dari 
faktor-faktor penilaian serta pengaruh dari faktor lainnya seperti kondisi industri perbankan dan perekonomian nasional. Tingkat kesehatan bank merupakan suatu keadaan serta kondisi keuangan dan manajemen bank yang diukur melalui rasio-rasio yang dihitung. Tingkat kesehatan bank adalah kepentingan semua pihak yang terkait baik pemilik maupun pengelola bank, masyarakat yang menggunakan jasa bank dan Bank Indonesia yang berperan selaku pembina dan pengawas bank-bank yang ada di Indonesia (Dyah A., Husaini dan Azizah, 2012).

Berdasarkan Peraturan Bank Indonesia No. 13/1/PBI/2011 dasar penilaian tingkat kesehatan bank dengan menggunakan pendekatan berdasarkan risiko atau RBBR (RiskBased Bank Rating) merupakan penilaian yang komprehensif dan terstruktur terhadap hasil kinerja dan profil risiko yang meliputi empat faktor penilaian yaitu Risk Profile (Profil risiko), Good Corporate Governance (GCG), Earning (Rentabilitas), dan Capital (Permodalan). Penilaian profil risiko dilakukan terhadap risiko inheren dan kualitas penerapan manajemen risiko dalam aktivitas operasional bank. Profil risiko yang dapat dianalisa yaitu risiko kredit dengan rasio NPL (Non Performing Loan) dan risiko likuiditas dengan rasio LDR (Loan to Deposit Ratio).

PT. Bank Papua adalah salah satu Bank Pembangunan Daerah yang merupakan salah satu badan usaha milik daerah yang berbentuk Perseroan Terbatas. PT. Bank Papua merupakan bank pembangunan daerah yang bergerak di bidang keuangan perbankan dan juga pelayanan terhadap penggunaan jasa keuangan. Bank Papua selama ini telah memberikan produk maupun fasilitas pelayanan yang bervariasi kepada pelanggannya sebagai bentuk usaha untuk meningkatkan mutu dalam aspek penilaian bagi nasabah atau pelanggan dan juga untuk kemudahan pelanggan dalam melakukan transaksi perbankan. Pada bulan Desember 2015 lalu Bank Papua telah mengalami kenaikan rasio kredit bermasalah. Hingga pada bulan Juni 2016, rasio kredit bermasalah Bank Papua telah mencapai Rp 1,5 triliun atau dengan persentase 11,18 yang mana hasil ini telah melebihi batas rasio kredit bermasalah yang ditetapkan oleh Otoritas Jasa Keuangan (OJK) yaitu dengan batas maksimum 5\% yang artinya standar rasio kredit bermasalah tidak boleh melewati batas maksimum tersebut (Lopes Costa, 2020).

Berdasarkan pemaparan di atas, maka perlunya dilakukan penelitian untuk tingkat kesehatan bank ini adalah agar dalam penetapan tingkat kualitas dan kebaikan bank dapat mudah dilakukan serta seluruh hal yang berkaitan dengan kemajuan dan kestabilan bank dapat terus konsisten dijaga dan diperhatikan. Salah satunya adalah permasalahan kredit macet. Bank Indonesia yang memiliki peran sebagai pengawas bank juga sangat memerlukan laporan tingkat kesehatan bank yang dimana perhitungan dan penilaiannya dari berbagai aspek. Bank yang sehat adalah bank dengan tingkat kinerja yang baik, laporan keuangan yang jelas dan akurat serta kestabilan seluruh aspeknya yang berkaitan.

Tujuan dalam penulisan artikel ini yaitu untuk menganalisis tingkat kesehatan Bank Papua periode tahun 2011-2018 dan untuk mengetahui performa Bank Papua dilihat dari indikator NPL, LDR, ROA, NIM, dan CAR.

Manfaat penulisan artikel yakni ada dua, pertama secara teoritis bagi perkembangan ilmu pengetahuan, hasil penelitian ini diharapkan dapat memperkaya khasanah dalam ilmu ekonomi dan perbankan serta menambah wawasan dan pengetahuan bagi pembaca mengenai penelitian tingkat kesehatan bank dengan metode RBBR (Risk Based Bank Rating) dan kedua 
secara praktis bagi industri perbankan, penelitian ini bermanfaat untuk memberikan informasi tambahan bagi pihak bank mengenai tingkat kesehatan bank sehingga manajemen bank dapat meningkatkan kinerjanya dan dapat menentukan strategi bisnis yang baik dalam menghadapi krisis keuangan global dan juga persaingan dalam dunia bisnis perbankan.

\section{KAJIAN LITERATUR \\ Tingkat Kesehatan Bank}

1. Pengertian Tingkat Kesehatan Bank

Tingkat kesehatan bank merupakan hasil dari penelitian kualitatif pada penilaian beberapa aspek yang berpengaruh terhadap keadaan atau kinerja suatu bank melalui penilaian kualitatif atau penilaian kualitatif terhadap beberapa faktor seperti permodalan, kualitas aset, manajemen, rentabilitas, likuiditas dan sensitivitas terhadap risiko pasar (Peraturan Bank Indonesia Nomor 6/10/PBI, 2008).

Tingkat kesehatan bank dapat didefinisikan yaitu dimana kemampuan suatu bank untuk melakukan kegiatan operasional perbankan secara rapi dan normal serta mampu melaksanakan kewajibannya secara keseluruhan dengan baik melalui caracara yang sesuai dengan peraturan dan ketetapan yang berlaku pada perbankan (Kasmir, 2008).

Tingkat kesehatan bank merupakan suatu cakupan batasan yang sangat luas, karena kesehatan bank memang mencakup kesehatan suatu bank untuk melaksanakan seluruh kegiatan usaha perbankannya. Kegiatan tersebut meliputi (Totok dan Sigit, 2006, hlm. 22):

a. Kemampuan bank menghimpun dana dari masyarakat, dari lembaga lain, dan dari modal sendiri.

b. Kemampuan bank dalam mengelola dana.

c. Kemampuan bank untuk menyalurkan dana ke masyarakat.

d. Kemampuan bank memenuhi kewajiban kepada masyarakat, karyawan, pemilik modal dan pihak lain.

e. Pemenuhan peraturan perbankan yang berlaku.

Dari beberapa pengertian di atas dapat disimpulkan bahwa penilaian tingkat kesehatan bank adalah kegiatan penilaian kinerja dan keseluruhan segala aspek dalam menunjang kegiatan operasional bank.

\section{Indikator Penilaian Tingkat Kesehatan Bank}

a. Struktur Permodalan

Struktur permodalan adalah jumlah modal tertentu secara aman dan seimbang yang harus dimiliki bank dibandingkan dengan dana yang harus siap tiba-tiba dikeluarkan apabila ada penarikan dana yang akan ditarik segera. Dengan kata lain, makin besar posisi modal sendiri dibandingkan dengan simpanan pihak ketiga/anggota yang dapat ditarik segera akan lebih baik struktur permodalannya. Modal dari bank terdiri dari modal inti dan modal pelengkap (Rustendi, 2011, hlm. 664). 
b. Faktor Kualitas Aktiva Produktif

Faktor kualitas produktif adalah kualitas aktiva bank yang dapat menghasilkan pendapatan/bagi hasil dihubungkan dengan pembiayaan bermasalah (Restandi, 2011, hlm. 665). Dalam menilai aktiva produktif ini pembiayaan bermasalah dapat dianalisis melalui dua cara:

1) Terhadap total pembiayaan yang diberikan, dan

2) Tersedianya dana penghapusan pembiayaan terhadap pembiayaan bermasalah. Makin kecil pembiayaan bermasalah terhadap total pembiayaan yang diberikan, maka akan makin baik kualitas aktiva produktif bank yang diperlukan dalam menghasilkan pendapatan. Makin besar dana penghapusan pembiayaan yang dapat diakumulasikan dari laba/pendapatan,dari masa ke masa terhadap pembiayaan bermasalah, pembiayaan bermasalah ini makin mudah diatasi, kekayaan aktiva produktif bank makin baik. Yang dimaksud pembiayaan bermasalah adalah pembiayaan yang telah tertunggak, melampaui masa perjanjian pengembaliannya sesuai dengan jenis pembiayaannya.

c. Faktor manajemen

Faktor manajemen ini meliputi 2 komponen yaitu manajemen umum dan manajemen resiko. Faktor manajemen ini meliputi aspek kesiapan bank untuk melakukan operasinya dilihat dari kelengkapan aturan-aturan dan mekanisme organisasi dalam perencanaan, pelaksanaan, pembinaan dan pengawasan. Faktor manajemen juga terkait pemenuhan peraturan perbankan yang berlaku (Purba, 2011, hlm. 201). Faktor manajemen lebih menekankan pada kesiapan bank dalam sistem dan prosedur kerja sehari-hari yang dijalankan oleh pengelola bank. Skala penilaian untuk setiap pertanyaan/pernyataan ditetapkan antara 0 sampai dengan 4 dengan kriteria:

1) Nilai 0 mencerminkan kondisi yang lemah,

2) Nilai 1,2, dan 3 mencerminkan kondisi antar,

3) Nilai 4 mencerminkan kondisi yang baik.

Hasil penjumlahan nilai yang diperoleh atas pertanyaan diperoleh nilai kredit. Nilai kredit ini dikalikan bobot yang ditetapkan, akan diperoleh angka nilai kredit faktor manajemen.

d. Likuiditas

Likuiditas adalah kemampuan bank untuk memenuhi kewajiban finansialnya yang segera harus dipenuhi. Bank dinilai sehat bila memiliki dana dalam jumlah yang aman/cukup, tidak terlalu kecil, sehingga mencukupi kalau ada yang menarik dana segera (Luthfiani, Kurniati dan Zunaida, 2016). Tidak terlalu besar sehingga mubazir, karena tidak produktif.

Pemberian nilai kredit untuk faktor likuiditas:

1) Untuk ratio alat likuid terhadap utang lancar:

a) Untuk ratio \% diberi nilai kredit 0

b) Untuk setiap kenaikan $0,05 \%$ mulai dari $0 \%$ nilai kredit ditambah 1 dengan nilai maksimum 100

2) Untuk ratio kredit yang diberikan terhadap dana yang diterima :

a) Untuk ratio $11,5 \%$ atau lebih diberi nilai kredit 0 
b) Untuk setiap penurunan $1 \%$ mulai dari $11,5 \%$ nilai kredit ditambah 4 dengan maksimum 100

e. Faktor Rentabilitas

Rentabilitas adalah kemampuan bank untuk menghasilkan laba. Penilaian rentabilitas didasarkan atas dua hal (Amelia Suhartono, Zahroh ZA dan Azizah ,2017, hlm. 138):

1) Perbandingan laba sebelum pajak 12 bulan terakhir terhadap rata-rata volume usaha dalam periode yang sama.

2) Perbandingan beban operasional terhadap pendapatan operasional 12 bulan terakhir.

Pemberian nilai kredit faktor rentabilitas:

1) Untuk ratio laba terhadap volume usaha:

a) Untuk ratio $\%$ atau negatif diberi nilai 0

b) Untuk setiap kenaikan $0,015 \%$ mulai dari 0 nilai kredit ditambah 1 dengan maksimum 100

2) Untuk ratio efisiensi:

a) Untuk ratio $100 \%$ diberi nilai kredit 0 , dan

b) Untuk setiap penurunan $100 \%$ nilai kredit ditambah 1 dengan maksimum 100

f. Keberhasilan Manajemen

Manajemen memegang peranan penting dalam mencapai tujuan perusahaan. Keberhasilan manajemen dalam mencapai fungsi-fungsinya guna mencapai tujuan bank diketahui dengan membandingkan antara perencanaan dengan realisasi operasi. Kegiatan evalusai untuk mengukur keberhasilan manajemen dilakukan dengan cara mengukur tingkat tingkat efisiensi dan efektivitas dalam pencapaian tujuan bank. Pengukuran efisiensi dengan cara membandingkan antara output dan input.

\section{Metode Risk Based Bank Rating (RBBR)}

Penilaian tingkat kesehatan bank dengan metode RBBR dibagi atas empat faktor.Faktor tersebut meliputi faktor profil risiko (risk profile), good corporate governance (GCG), rentabilitas (earning), dan permodalan (capital), (Ikatan Bankir Indonesia (IBI), 2018, hlm. 226).

Menurut Pasal 2 Peraturan Bank Indonesia No. 13/1/PBI/2011 dijelaskan bahwa bank wajib melakukan penilaian kesehatan bank dengan menggunakan metode pendekatan risiko (Risk Based Bank Rating).

1. Profil Risiko (Risk Profile)

Berdasarkan pasal 1 PBI No. 11/25/PBI/2009 penilaian terhadap faktor profil risiko inheren dan kualitas penilaian manajemen resiko dalam operasional bank yang dilakukan terhadap 8 (delapan) resiko yaitu (Peraturan Otoritas Jasa Keuangan Nomor 4/POJK.03/2016):
a. Risiko Kredit
b. Risiko Pasar
c. Risiko Likuiditas
d. Risiko Operasional 

e. Risiko Hukum
f. Risiko Stratejik
g. Risiko Reputasi
h. Risiko Kepatuhan

\section{Good Corporate Governance (GCG)}

Salah satu indikator yang digunakan untuk menilai tingkat kesehatan bank adalah GCG. Penilaian GCG mencakup governance structure, governance process dan governance outcome. Berdasarkan PBI No. 8/4/PBI/2006 Good Corporate Governance adalah suatu tata kelola bank yang menerapkan prinsip-prinsip keterbukaan (transparency), akuntabilitas (accountability), pertanggungjawaban (responsibility), independensi (independency) dan kewajaran (fairness). Prinsip dasar GCG adalah transparansi yang diartikan sebagai keterbukaan informasi, baik dalam proses pengambilan keputusan maupun dalam mengungkapkan informasi material dan relevan mengenai perusahaan (Ikatan Bankir Indonesia (IBI), 2018, hlm. 229).

3. Rentabilitas (Earning)

Penilaian tingkat kesehatan bank yang melihat kemampuan bank dalam menghasilkan laba. Penilaian rentabilitas bank terdiri dari penilaian atas kineja rentabilitas, sumber-sumber rentabilitas, dan manajemen rentabilitas, dimana penilaian dilakukan dengan menggunakan indikator kuantitatif dan kualitatif (Ikatan Bankir Indonesia (IBI), 2018, hlm. 229). Penilaian rentabilitas menghasilkan peringkat rentabilitas yang dikategorikan dalam 5 peringkat yaitu peringkat 1 , peringkat 2 , peringkat 3 , peringkat 4 , dan peringkat 5 . Urutan peringkat yang lebih kecil mencerminkan kinerja rentabilitas yang lebih baik.

4. Permodalan (Capital)

Penilaian atas faktor permodalan meliputi pengawasan dan pengendalian terhadap kecukupan permodalan dan kecukupan pengelolaan permodalan. Dalam melakukan perhitungan permodalan, bank wajib mengacu pada ketentuan Bank Indonesia yang mengatur mengenai kewajiban penyediaan modal minimum bagi bank umum. Dalam melakukan tindakan penilaian kecukupan permodalan, bank harus pula mengaitkan kecukupan modal dengan Profil Risiko Bank. Semakin tinggi risiko bank, semakin besar modal yang harus disediakan untuk mengantisipasi risiko tersebut. Rasio yang dapat digunakan untuk mengukur kecukupan modal yang dimiliki bank adalah Capital Adequacy Ratio (CAR).Berdasarkan SE BI No 26/2/BPPP mengatur bahwa kewajiban penyediaan modal minimum atau CAR diukur dari persentase tertentu terhadap Aktiva Tertimbang Menurut Risiko (ATMR) sebesar 8\% dari ATMR.

\section{Hipotesis}

1. $\mathrm{H}_{\mathrm{a}}$ : Analisis tingkat kesehatan Bank Papua menggunakan metode RBBR (Risk Based Bank Rating) Periode Tahun 2011-2018 dinyatakan sehat.

$\mathrm{H}_{0}$ : Analisis tingkat kesehatan Bank Papua menggunakan metode RBBR (Risk Based Bank Rating) Periode Tahun 2011-2018 dinyatakan tidak sehat. 
2. $\mathrm{H}_{\mathrm{a}}$ : Performa Bank Papua dilihat dari indicator NPL, LDR, ROA, NIM dan CAR dinyatakan baik.

$\mathrm{H}_{0}$ : Performa Bank Papua dilihat dari indicator NPL, LDR, ROA, NIM dan CAR dinyatakan tidak baik.

\section{METODE PENELITIAN}

Penelitian ini menggunakan metode penelitian deskriptif dengan pendekatan kuantitatif. Penelitian deskriptif dengan pendekatan kuantitaif adalah penelitian terhadap suatu objek untuk memuat deskripsi dan gambaran sistematis mengenai fakta-fakta objek yang diteliti, dengan menggunakan data berupa angka sebagai alat untuk menganalisis. Penelitian kuantitatif harus disusun secara teliti, detail, dan sistematis mengenai penjabaran angkaangka dari suatu data. Dalam penelitian ini, peneliti akan melakukan analisis data sekunder menggunakan rumus-rumus yang terdapat dipenjelasan mengenai teknik analisis data. Setelah data sekunder telah diolah barulah akan didapat hasil yang dibutuhkan peneliti yang kemudian akan dideskripsikan sebagai hasil penelitian.

\section{Teknik Analisis Data}

Analisis data yang digunakan oleh peneliti adalah:

1. Analisis Risk Profile (Profil Risiko)

Analisis Risk Profile (Profil Risiko) dihitung dengan menggunakan rasio kredit yaitu Noan Performing Loan (NPL) dan Loan to Deposit Ratio (LDR).

a. Risiko Kredit

$$
\mathrm{NPL}=\frac{\text { Kredit Bermasalah }}{\text { Total Kredit }} \times 100 \%
$$

Tabel 1 Predikat kesehatan bank berdasarkan NPL

\begin{tabular}{|c|c|c|}
\hline No & Rasio & Predikat \\
\hline 1 & $0 \%<\mathrm{NPL}<2 \%$ & Sangat Sehat \\
\hline 2 & $2 \%<\mathrm{NPL}<5 \%$ & Sehat \\
\hline 3 & $5 \%<\mathrm{NPL}<8 \%$ & Cukup Sehat \\
\hline 4 & $8 \%<\mathrm{NPL}<11 \%$ & Kurang Sehat \\
\hline 5 & NPL $>11 \%$ & Tidak Sehat \\
\hline
\end{tabular}

(Sumber: SE BI 6/23/DPNP)

b. Risiko Likuiditas

$$
\text { LDR }=\frac{\text { Total Kredit }}{\text { Dana Pihak Ketiga }} \times 100 \%
$$

Tabel 2 Predikat kesehatan bank berdasarkan LDR

\begin{tabular}{|c|c|c|}
\hline No & Rasio & Predikat \\
\hline 1 & $50 \%<\mathrm{LDR}<75 \%$ & Sangat Sehat \\
\hline 2 & $75 \%<\mathrm{LDR}<85 \%$ & Sehat \\
\hline 3 & $85 \%<\mathrm{LDR}<100 \%$ & Cukup Sehat \\
\hline 4 & $100 \%<\mathrm{LDR}<120 \%$ & Kurang Sehat \\
\hline
\end{tabular}




\begin{tabular}{|c|c|c|}
\hline 5 & LDR $>120 \%$ & Tidak Sehat \\
\hline
\end{tabular}

(Sumber: SE BI 6/23/DPNP)

2. Analisis Earning (Rentabilitas)

Analisis Earning (Rentabilitas) dihitung dengan menggunakan rasio Return On Assets (ROA) dan Net Interest Margin (NIM).

a. Return On Assets (ROA)

$$
\mathrm{ROA}=\frac{\text { Laba Sebelum Pajak }}{\text { Total Asset }} \times 100 \%
$$

Tabel 3 Predikat kesehatan bank berdasarkan ROA

\begin{tabular}{|c|c|c|}
\hline No & Rasio & Predikat \\
\hline 1 & $2 \%<\mathrm{ROA}$ & Sangat Sehat \\
\hline 2 & $1,25 \%<\mathrm{ROA}<2 \%$ & Sehat \\
\hline 3 & $0,5 \%<\mathrm{ROA}<1,25 \%$ & Cukup Sehat \\
\hline 4 & $0 \%<\mathrm{ROA}<0,5 \%$ & Kurang Sehat \\
\hline 5 & $\begin{array}{c}\text { ROA }<0 \%(\text { atau } \\
\text { negatif })\end{array}$ & Tidak Sehat \\
\hline
\end{tabular}

(Sumber: SE BI 6/23/DPNP)

b. Net Interest Margin (NIM)

$\mathrm{NIM}=\frac{\text { Pendapatan Bunga Bersih }}{\text { Rata-Rata Aktiva Produktif }} \times 100 \%$

Tabel 4 Predikat kesehatan bank berdasarkan LDR

\begin{tabular}{|c|c|c|}
\hline No & Rasio & Predikat \\
\hline 1 & $3 \%<\mathrm{NIM}$ & Sangat Sehat \\
\hline 2 & $2 \%<\mathrm{NIM}<3 \%$ & Sehat \\
\hline 3 & $1,5 \%<\mathrm{NIM}<2 \%$ & Cukup Sehat \\
\hline 4 & $1 \%<\mathrm{NIM}<1,5 \%$ & Kurang Sehat \\
\hline 5 & $\mathrm{NIM}<1 \%$ & Tidak Sehat \\
\hline
\end{tabular}

(Sumber: SE BI 6/23/DPNP)

3. Analisis Capital (Permodalan), yaitu dengan menggunaka rasio Capital Adequency Ratio (CAR)

$$
\mathrm{CAR}=\frac{\text { Modal }}{\text { Total ATMR }} \times 100 \%
$$

Tabel 5 Predikat kesehatan bank berdasarkan CAR

\begin{tabular}{|c|c|c|}
\hline No & Rasio & Predikat \\
\hline 1 & $12 \%<\mathrm{CAR}$ & Sangat Sehat \\
\hline 2 & $9 \%<\mathrm{CAR}<12 \%$ & Sehat \\
\hline 3 & $8 \%<\mathrm{CAR}<9 \%$ & Cukup Sehat \\
\hline 4 & $6 \%<\mathrm{CAR}<8 \%$ & Kurang Sehat \\
\hline 5 & CAR $<6 \%$ & Tidak Sehat \\
\hline
\end{tabular}


(Sumber: SE BI 6/23/DPNP)

\section{HASIL DAN PEMBAHASAN}

Hasil

1. Deskripsi Rasio Keuangan Bank Papua Periode 2011-2018

Tabel 6 Data Rasio Keuangan Bank Papua Periode 2011-2018

\begin{tabular}{|c|c|c|c|c|c|}
\hline \multirow{2}{*}{ TAHUN } & \multicolumn{4}{|c|}{ RASIO KEUANGAN DALAM PERSEN (\%) } \\
\cline { 2 - 6 } & NPL & LDR & ROA & NIM & CAR \\
\hline $\mathbf{2 0 1 1}$ & 1,09 & 47,91 & 2,86 & 7,32 & 26,77 \\
\hline $\mathbf{2 0 1 2}$ & 0,84 & 71,65 & 2,81 & 5,71 & 21,42 \\
\hline $\mathbf{2 0 1 3}$ & 1,14 & 84,48 & 2,86 & 7,88 & 18,40 \\
\hline $\mathbf{2 0 1 4}$ & 7,33 & 80,12 & 1,02 & 7,59 & 16,28 \\
\hline $\mathbf{2 0 1 5}$ & 9,63 & 83,03 & 2,60 & 7,51 & 22,22 \\
\hline $\mathbf{2 0 1 6}$ & 15,03 & 86,23 & $-0,61$ & 7,01 & 17,28 \\
\hline $\mathbf{2 0 1 7}$ & 14,72 & 80,12 & 0,61 & 7,16 & 17,99 \\
\hline $\mathbf{2 0 1 8}$ & 7,45 & 78,90 & 1,24 & 6,82 & 22,21 \\
\hline
\end{tabular}

(Sumber: Annual Report Bank Papua 2018)

Tabel 6 menunjukkan rasio keuangan Bank Papua Tahun 2011-2018 yang terdiri dari rasio NPL (Non Performing Loan), LDR (Loan to Deposit Ratio), ROA (Return on Assets), NIM (Net Interest Margin), dan CAR (Capitally Adequency Ratio).

a. Deskripsi Rasio Non Performing Loan (NPL)

Rasio NPL merupakan rasio yang menghitung mengenai besar nilai kredit bermasalah pada bank. Berdasarkan data pada tabel 6 dapat dilihat bahwa besar nilai rasio NPL Bank Papua tahun 2011 adalah 1,09\% yang kemudian turun kembali pada tahun 2012 sebesar 0,84\% dan kembali naik pada tahun 2013 sebesar 1,14\%. Selanjutnya di tahun 2014-2017 nilai NPL pada Bank Papua terus mengalami peningkatan hingga mencapai angka $15,03 \%$ yang kemudian secara signifikan turun kembali di tahun 2018.

Hal tersebut menunjukkan bahwa Bank Papua memiliki nilai NPL yang mengalami pekembangan secara fluktuatif yang dimana nilai tertinggi NPL Bank Papua periode 2011-2018 terletak pada tahun 2016 sebesar 15,03\% dan nilai terendah NPL Bank Papua periode tahun 2011-2018 terletak di tahun 2012 sebesar $0.84 \%$. 


\section{Gambar 1 Grafik Rasio NPL Bank Papua Periode 2011-2018}

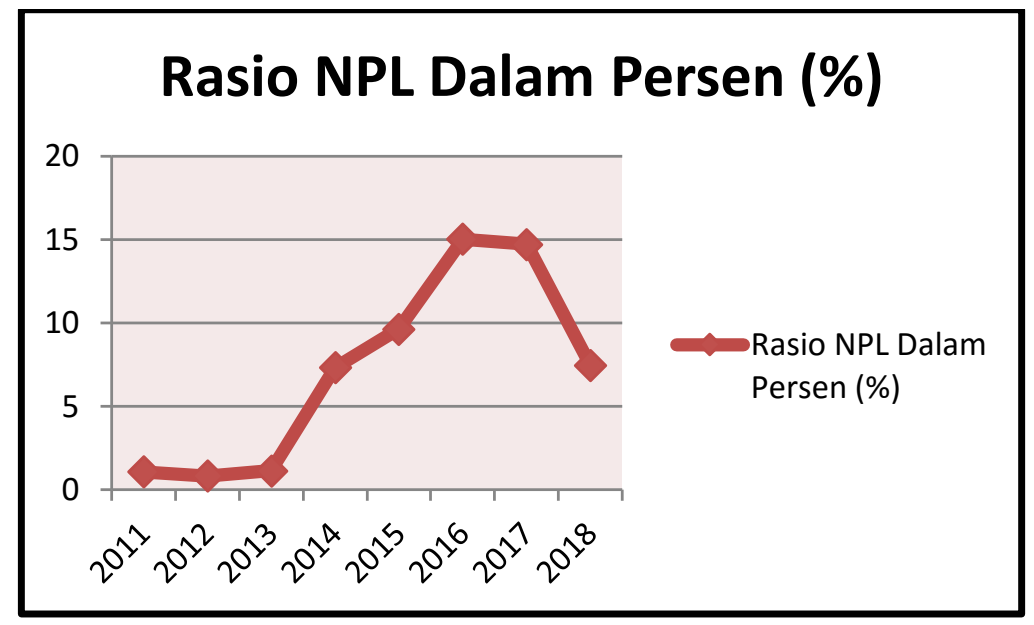

(Sumber: Data Sekunder Diolah Oleh Peneliti, 2020)

b. Deskripsi Rasio Loan to Deposit Ratio (LDR)

Rasio LDR merupakan rasio yang menghitung mengenai total kredit yang berbanding dengan dana pihak ketiga yang terdapat pada bank. Pada tabel 6 dapat dideskripisikan bahwa nilai LDR Bank Papua pada tahun 2011-2012 mengalami penurunan dan kemudian kembali mengalami kenaikan di tahun 2013 sebesar $84,48 \%$. Hal tersebut mempelihatkan bahwa perkembangan LDR Bank Papua bergerak secara fluktuatif.

Pada tahun 2014-2018 pun nilai LDR Bank Papua terus mengalami perkembangan secara tidak konstan yang dimana besar LDR bergerak secara naik turun. Nilai LDR Bank Papua periode 2011-2018 yang tertinggi terletak pada tahun 2016 sebesar 86,23\% dan yang terendah terdapat di tahun 2011 sebesar 47,91\%.

Gambar 2 Grafik Rasio NPL Bank Papua Periode 2011-2018

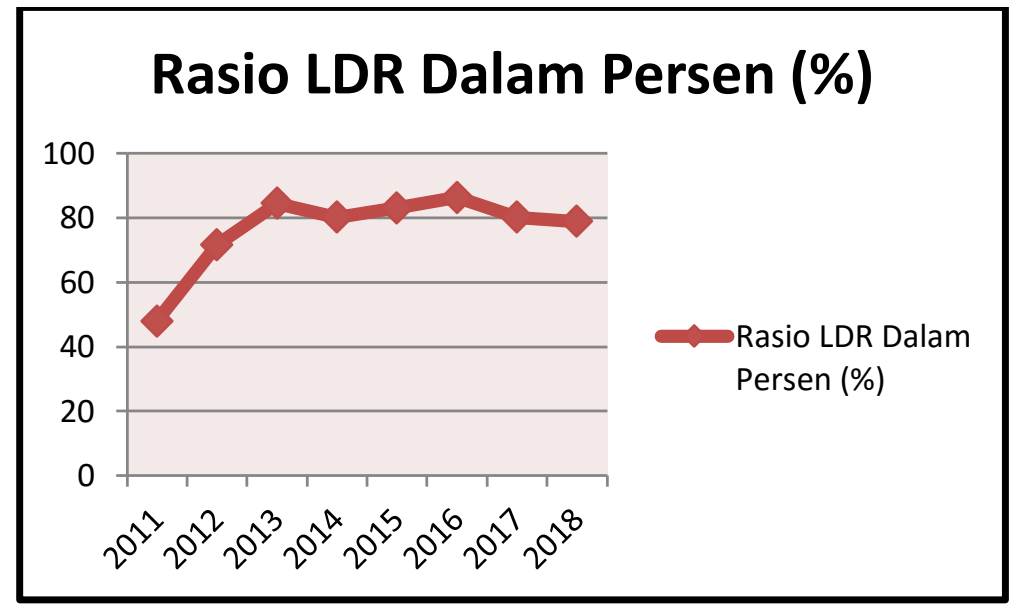

(Sumber: Data Sekunder Diolah Oleh Peneliti, 2020) 
c. Deskripsi Rasio Return on Assets (ROA)

Rasio ROA merupakan rasio keuangan pada bank yang digunakan untuk mengukur kemampuan bank dalam menghasilkan laba yang ditanam pada dana di seluruh aktiva produktif.

Pada tabel 6 telah digambarkan perkembangan nilai ROA pada Bank Papua sejak tahun 2011-2018. Nilai ROA pada Bank Papua mengalami perkembangan yang bergerak secara naik turun yang berarti perkembangan pergerakan nilai ROA Bank Papua adalah secara fluktuatif. Pada tahun 2011-2012 nilai ROA Bank Papua turun sebesar $0,5 \%$ dari nilai $2,86 \%$ menjadi $2,81 \%$. Pada tahun 2013, nilai ROA naik kembali menjadi sebesar 2,86\%. Sementara di tahun 2014 kembali mengalami penurunan sebesar $1,84 \%$ yang berarti nilai ROA di tahun tersebut sebesar $1,02 \%$ dan kembali naik di tahun 2015 hingga angka 2,60\%. Lalu turun secara signifikan di tahun 2016 hingga mencapai nilai di titik negatif sebesar $-0,61 \%$ dan pada dua tahun selanjutnya nilai ROA kembali naik.

Nilai tertinggi ROA Bank Papua terletak pada tahun 2011 dan 2013 sebesar 2,86\% dan nilai terendah ROA Bank Papua terletak di tahun 2017 dengan angka $0,61 \%$.

Gambar 3 Grafik Rasio ROA Bank Papua Periode 2011-2018

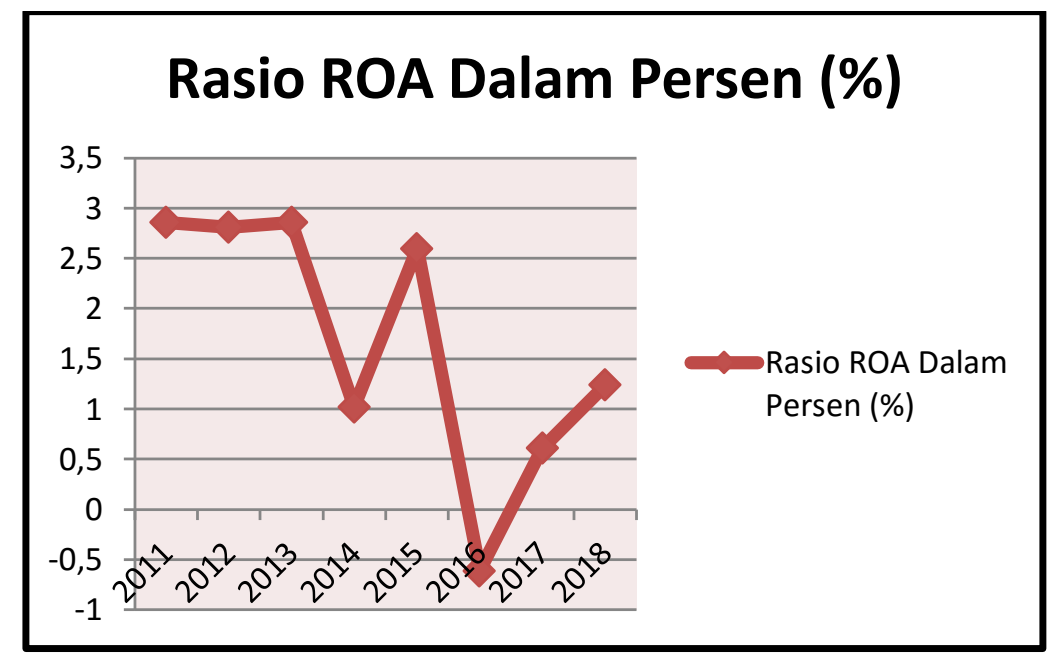

(Sumber: Data Sekunder Diolah Oleh Peneliti, 2020)

\section{d. Deskripsi Rasio Net Interest Margin (NIM)}

Rasio NIM merupakan perhitungan pendapatan bunga bersih yang berbanding dengan rata-rata aktiva produktif. Pendapatan bunga bersih merupakan pendapatan bunga yang telah dikurangi dengan beban bunga. Aktiva produktif yang dihitung adalah total dari aset bank.

Tabel 6 telah memperlihatkan perkembangan nilai NIM Bank Papua tahun 2011-2018. Pada tahun 2011 nilai NIM Bank Papua sebesar 7,32\% yang kemudian turun pada tahun 2012 sebesar 5,71\%. Lalu naik kembali di tahun 2013 hingga mencapai nilai 7,88\% yang kemudian ditahun-tahun selanjutnya hingga tahun 2018 selalu mengalami penurunan sampai pada nilai $6,82 \%$. Hal tersebut menjelaskan bahwa perkembangan nilai NIM Bank Papua bergerak secara fluktuatif di tiga 
tahun pertama pada periode 2011-2018 yaitu tahun 2011,2012, dan 2013 lalu kemudian secara konstan bergerak turun dari tahun 2014-2018. Nilai tertinggi NIM Bank Papua terdapat pada tahun 2013 dengan angka 7,88\% dan nilai NIM terendah Bank Papua terletak di tahun 2012 sebesar 5,71\%.

Gambar 4 Grafik Rasio NIM Bank Papua Periode 2011-2018

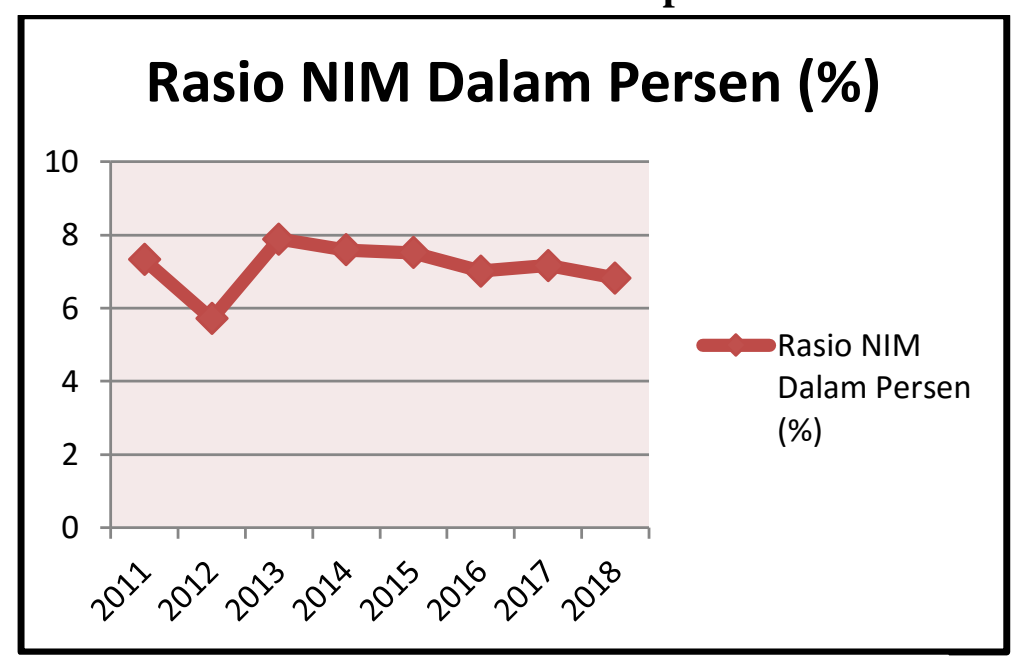

(Sumber: Data Sekunder Diolah Oleh Peneliti, 2020)

\section{e. Deskripsi Rasio Capitally Adequency Ratio (CAR)}

Rasio CAR adalah rasio untuk mengukur permodalan. CAR adalah kecukupan penyediaan modal yang menunjukkan kemampuan bank dalam mempertahankan modal dan kemampuan manajemen bank dalam mengukur dan mengawasi serta melihat risiko-risiko yang akan timbul yang dapat berpengaruh terhadap besarnya modal bank. Pada tabel 6, rasio CAR Bank Papua bergerak secara tidak konstan yang berarti perkembangan pergerakan CAR Bank Papua pada peiode tahun 2011-2018 adalah secara fluktuatif. Pada tahun 2011-2014 secara konstan dan stabil mengalami penurunan dan pada tahun 2015 kembali naik sebesar 22,22\% yang kemudian turun kembali hingga tahun 2017 sebesar 17,99\% dan pada tahun 2018 kembali mengalami kenaikan. Hal ini menunjukkan bahwa rasio CAR pada Bank Papua periode tahun 2011-2018 bergerak secara stabil. Nilai CAR Bank Papua yang tertinggi terdapat pada tahun 2011 sebesar 26,77\% dan nilai terendah CAR Bank Papua terletak di tahun 2014 sebesar 16,28\%. 
Gambar 5 Rasio CAR Bank Papua Periode 2011-2018

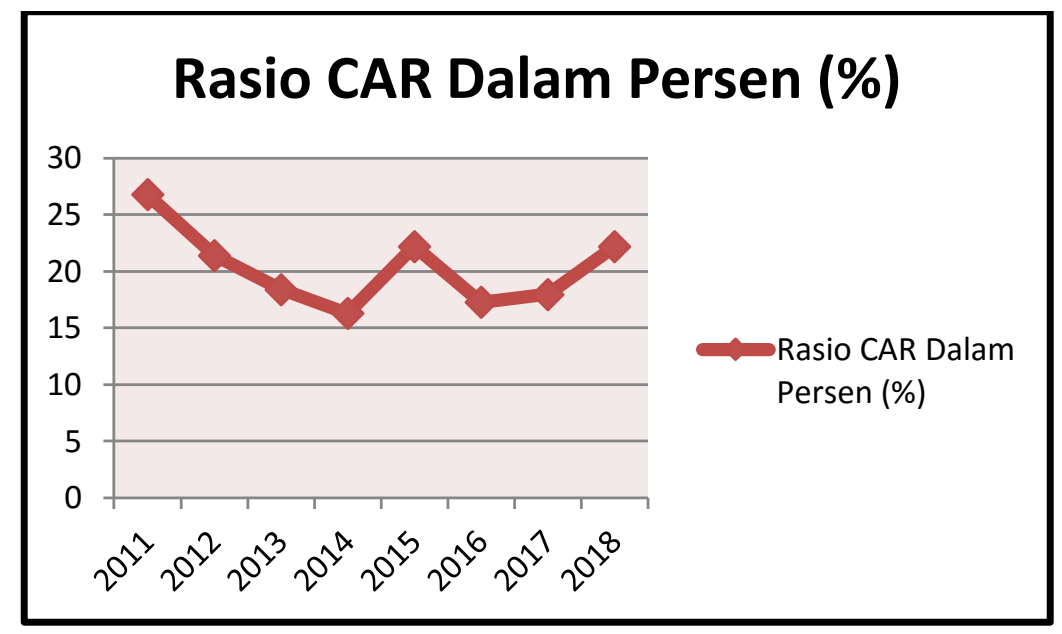

(Sumber: Data Sekunder Diolah Oleh Peneliti, 2020)

2. Analisis Tingkat Kesehatan Bank Papua dengan Metode Risk Based Bank Rating (RBBR)

a. Analisis Risk Profile (Profil Risiko)

Penilaian terhadap risiko inheren dan kualitas penerapan manajemen risiko dalam kegiatan operasional terhadap delapan risiko, yaitu risiko kredit, risiko pasar, risiko likuiditas, risiko operasional, risiko hukum, risiko stratejik, risiko kepatuhan, dan risiko reputasi (Peraturan Bank Indonesia No. 13/1/PBI/2011). Dalam penelitian ini mengukur risiko kredit dan risiko likuiditas pada faktor risk profile. Risiko kredit menggunakan rasio Non Performing Loan (NPL) dan risiko likuiditas menggunakan rasio Loan to Deposit Ratio (LDR).

1) Rasio Non Performing Loan (NPL)

Tabel 7 Rasio NPL Bank Papua Periode 2011-2018

\begin{tabular}{|c|c|c|}
\hline Tahun & Rasio NPL (\%) & Predikat \\
\hline 2011 & 1,09 & SS \\
\hline 2012 & 0,84 & SS \\
\hline 2013 & 1,14 & SS \\
\hline 2014 & 7,33 & CS \\
\hline 2015 & 9,63 & KS \\
\hline 2016 & 15,03 & TS \\
\hline 2017 & 14,72 & TS \\
\hline 2018 & 7,45 & CS \\
\hline
\end{tabular}

(Sumber: Data sekunder diolah oleh peneliti, 2020)

Keterangan :

SS : Sangat Sehat

S : Sehat

CS : Cukup Sehat

KS : Kurang Sehat

TS : Tidak Sehat 
Berdasarkan tabel 4.2, rasio NPL Bank Papua periode tahun 2011-2018 mengalami fluktuasi yang berarti pergerakan perkembangan NPL Bank Papua tidak stabil. Ada dua tahun dimana nilai NPL Bank Papua mencapai nilai tertinggi yang mengakibatkan Bank Papua mendapat predikat tidak sehat, yaitu pada tahun 2016 dan 2017.

2) Rasio Loan to Deposit Ratio (LDR)

Tabel 8 Rasio LDR Bank Papua Periode 2011-2018

\begin{tabular}{|c|c|c|}
\hline Tahun & Rasio LDR (\%) & Predikat \\
\hline 2011 & 47,91 & SS \\
\hline 2012 & 71,65 & SS \\
\hline 2013 & 84,48 & S \\
\hline 2014 & 80,12 & S \\
\hline 2015 & 83,03 & S \\
\hline 2016 & 86,23 & CS \\
\hline 2017 & 80,12 & S \\
\hline 2018 & 78,90 & S \\
\hline
\end{tabular}

(Sumber: Data sekunder diolah oleh peneliti, 2020)

Keterangan :

SS : Sangat Sehat

S : Sehat

CS : Cukup Sehat

KS : Kurang Sehat

TS : Tidak Sehat

Tabel di atas memperlihatkan bahwa perkembangan LDR Bank Papua bergerak secara tidak stabil yang mana pergerakannya adalah fluktuatif. Namun demikian, nilai LDR Bank Papua masih masuk dalam kategori yang baik. LDR Bank Papua yang paling tinggi terletak pada tahun 2016 yang menyebabkan Bank Papua hanya mendapat predikat cukup sehat.

b. Analisis Earning (Rentabilitas)

Penilaian earning Bank Papua menggunakan parameter diantaranya adalah:

1) Rasio Return On Assets (ROA)

Tabel 9 Rasio ROA Bank Papua Periode 2011-2018

\begin{tabular}{|c|c|c|}
\hline Tahun & Rasio ROA (\%) & Predikat \\
\hline 2011 & 2,86 & SS \\
\hline 2012 & 2,81 & SS \\
\hline 2013 & 2,86 & SS \\
\hline 2014 & 1,02 & S \\
\hline 2015 & 2,60 & SS \\
\hline 2016 & $-0,61$ & TS \\
\hline 2017 & 0,61 & CS \\
\hline 2018 & 1,24 & CS \\
\hline
\end{tabular}

(Sumber: Data sekunder diolah oleh peneliti, 2020) 
Keterangan :

SS : Sangat Sehat

S : Sehat

CS : Cukup Sehat

KS : Kurang Sehat

TS : Tidak Sehat

Berdasarkan tabel di atas, nilai ROA Bank Papua begerak secara naik turun dan tidak stabil. ROA Bank Papua yang terendah terdapat di tahun 2016 yang mencapai titik nilai negatif yaitu $-0,61 \%$ yang mana nilai tersebut memberikan predikat tidak sehat untuk Bank Papua.

2) Rasio Net Interest Margin (NIM)

Tabel 10 Rasio NIM Bank Papua Periode 2011-2018

\begin{tabular}{|c|c|c|}
\hline Tahun & Rasio NIM (\%) & Predikat \\
\hline 2011 & 7,32 & SS \\
\hline 2012 & 5,71 & SS \\
\hline 2013 & 7,88 & SS \\
\hline 2014 & 7,59 & S \\
\hline 2015 & 7,51 & SS \\
\hline 2016 & 7,01 & SS \\
\hline 2017 & 7,16 & SS \\
\hline 2018 & 6,82 & SS \\
\hline
\end{tabular}

(Sumber: Data sekunder diolah oleh peneliti, 2020)

Keterangan :

SS : Sangat Sehat

S : Sehat

CS : Cukup Sehat

KS : Kurang Sehat

TS : Tidak Sehat

Tabel di atas mempelrihatkan bahwa nilai rasio NIM Bank Papua Periode 2011-2018 berada pada predikat sangat sehat. Hal tersebut dapat ditarik dari data yang ada pada tabel 4.5 bahwa nilai NIM tidak ada yang berada dibawah nilai $3 \%$.

c. Analisis Capital (Permodalan)

Analisis permodalan dapat diukur menggunakan rasio Capital Adequncy Ratio (CAR).

Tabel 11 Rasio CAR Bank Papua Periode 2011-2018

\begin{tabular}{|c|c|c|}
\hline Tahun & Rasio CAR $(\boldsymbol{\%})$ & Predikat \\
\hline 2011 & 26,77 & SS \\
\hline 2012 & 21,42 & SS \\
\hline 2013 & 18,40 & SS \\
\hline 2014 & 16,28 & SS \\
\hline 2015 & 22,22 & SS \\
\hline
\end{tabular}




\begin{tabular}{|l|l|l|}
\hline 2016 & 17,28 & SS \\
\hline 2017 & 17,99 & SS \\
\hline 2018 & 22,21 & SS \\
\hline
\end{tabular}

(Sumber: Data sekunder diolah oleh peneliti, 2020)

Keterangan :

SS : Sangat Sehat

$S$ : Sehat

CS : Cukup Sehat

KS : Kurang Sehat

TS : Tidak Sehat

Tabel 11 mendeskripsikan bahwa nilai CAR Bank Papua periode 2011-2018 bergerak secara fluktuatif dan tidak stabil. Namun demikian, nilai CAR Bank Papua tetap berada pada kategori yang sangat bagus sehingga Bank Papua layak mendaatkan predikat sangat sehat berdasarkan nilai rasio CAR di tahun 2011-2018.

3. Performa Bank Papua Berdasarkan Lima (5) Indikator Metode Risk Based Bank Rating (RBBR)

Dalam metode RBBR ada lima indikatr yang digunakan, yaitu Non Performing Loan (NPL), Loan to Deposit Ratio (LDR), Return On Assets (ROA), Net Interest Margin (NIM) dan Capital Adequency Ratio (CAR).

Tabel 12 Nilai Rata-rata Lima Indikator Metode RBBR

\begin{tabular}{|c|c|c|c|c|c|}
\hline \multirow{2}{*}{ Tahun } & \multicolumn{5}{|c|}{ Rasio Keuangan (\%) } \\
\cline { 2 - 6 } & NPL & LDR & ROA & NIM & CAR \\
\hline $\mathbf{2 0 1 1}$ & 1,09 & 47,91 & 2,86 & 7,32 & 26,77 \\
\hline $\mathbf{2 0 1 2}$ & 0,84 & 71,65 & 2,81 & 5,71 & 21,42 \\
\hline $\mathbf{2 0 1 3}$ & 1,14 & 84,48 & 2,86 & 7,88 & 18,4 \\
\hline $\mathbf{2 0 1 4}$ & 7,33 & 80,12 & 1,02 & 7,59 & 16,28 \\
\hline $\mathbf{2 0 1 5}$ & 9,63 & 83,03 & 2,6 & 7,51 & 22,22 \\
\hline $\mathbf{2 0 1 6}$ & 15,03 & 86,23 & $-0,61$ & 7,01 & 17,28 \\
\hline $\mathbf{2 0 1 7}$ & 14,72 & 80,12 & 0,61 & 7,16 & 17,99 \\
\hline $\mathbf{2 0 1 8}$ & 7,45 & 78,9 & 1,24 & 6,82 & 22,21 \\
\hline Rata-Rata & $\mathbf{7 , 1 5}$ & $\mathbf{7 6 , 5 6}$ & $\mathbf{1 , 6 7}$ & $\mathbf{7 , 1 3}$ & $\mathbf{2 0 , 3 2}$ \\
\hline
\end{tabular}

(Sumber: Data Sekunder Diolah oleh peneliti, 2020)

a. Indikator Non Performing Loan (NPL)

Dalam tabel 12 dituliskan bahwa besar nilai rata-rata rasio NPL Bank Papua periode tahun 2011-2018 adalah sebesar 7,15\%. Hal tersebut menggambarkan bahwa rata-rata nilai NPL Bank Papua masuk dalam kategori baik yang menandakan Bank Papua berada pada predikat cukup sehat. 
b. Indikator Loan to Deposit Ratio (LDR)

Berdasarkan dari hasil rata-rata pada tabel 12 , nilai rata-rata dari rasio LDR Bank Papua periode tahun 2011-2018 adalah 76,56\% yang mana dengan nilai tersebut berarti menandakan bahwa nilai rata-rata LDR tersebut menempatkan Bank Papua termasuk dalam kategori baik yang berarti Bank Papua ada pada predikat sehat.

c. Indikator Return On Assets (ROA)

Nilai rata-rata rasio ROA Bank Papua dilihat dari tabel 12 adalah sebesar $1,67 \%$. Nilai tersebut memposisikan Bank Papua berada pada kategori baik dengan keterangan berada pada predikat sehat.

d. Indikator Net Interest Margin (NIM)

Besar nilai rata-rata rasio NIM Bank Papua berdasaraka tabel 12 adalah sebesar 7,13\%. Nilai tersebut menandakan bahwa Bank Papua berada pada kategori yang sangat baik sehingga dengan nilai rata-rata tersebut Bank Papua mendapat predikat sangat sehat yang berdasarkan besar nilai rata-rata rasio NIM.

e. Indikator Capital Adequency Ratio (CAR)

Nilai rata-rata rasio CAR Bank Papua periode tahun 2011-2018 berdasarkan pada tabel 12 adalah sebesar 20,32\%. Dengan besar nilai rata-rata CAR tersebut mengartikan bahwa keadaan kecukupan modal Bank Papua periode tahun 2011-2018 berada pada kategori sangat baik yang berarti juga berdasarkan hasil tersebut maka keadaan Bank Papua periode 2011-2018 dilihat dari rasio CAR adalah berpredikat sangat sehat.

\section{Pembahasan}

1. Tingkat Kesehatan Bank Papua Menggunakan Metode Risk Based Bank Rating (RBBR)

\section{a. Faktor Risk Profile (Profil Risiko)}

1) Risiko Kredit

Risiko kredit adalah risiko yang ditimbulkan akibat ketidakmampuan debitur atau pihak lainnya dalam memenuhi kewajibannya kepada bank atau yang lebih dikenal dengan kredit bermasalah atau kredit macet. Berdasarkan hasil penelitian bahwa NPL tertinggi terjadi pada tahun 2016 dan 2017 dengan nilai $15,03 \%$ dan $14,72 \%$. Hal tersebut terjadi karena Bank Papua banyak memberikan kredit kepada debitur di luar daerah contohnya ke Jakarta, Tangerang, Makassar dan Bali (Boedi Armanto, 2020). Lalu, NPL terendah terjadi pada tahun 2012 dengan besar 0,84\%. Nilai rata-rata rasio NPL Bank Papua periode tahun 2011-2018 adalah sebesar 7,15\%. Berdasarkan nilai tersebut dapat disimpulkan bahwa kesehatan Bank Papua termasuk ke dalam predikat cukup sehat.

Hal ini sejalan dengan penelitian yang telah dilakukan terlebih dahulu oleh Dina Ludia Marwa dan Aprianto L. Kuddy yang berjudul Menilai Tingkat Kesehatan Bank Papua menggunakan Metode Altman Z-Score dan Camel dengan hasil yang menunjukkan bahwa perhitungan nilai NPL berdasarkan metode Camel juga memperlihatkan kesehatan Bank Papua yang berada pada 
predikat cukup sehat. Sehingga dari hasil perhitungan NPL Bank Papua periode tahun 2011-2018, kesehatan Bank Papua berada pada predikat cukup sehat karena nilai NPL yang berada di atas 5\%. Semakin besar nilai NPL maka menandakan kondisi kesehatan bank semakin tidak sehat.

2) Risiko Likuiditas

Risiko Likuiditas adalah risiko yang terjadi akibat ketidaksanggupan bank dalam memenuhi kewajibannya yang seharusnya dibayarkan dan telah berada pada tanggal jatuh tempo. Berdasarkan hasil penelitian pada tabel 4.7, rata-rata LDR Bank Papua periode 2011-2018 adalah 76,56\%. LDR terbesar ada pada tahun 2013 dan 2016 dengan nilai 84,48\% dan 86,23\%. Sementara nilai LDR terendah berada pada tahun 2012 dengan nilai sebesar 76,65\%.

Dari hasil nilai rata-rata LDR Bank Papua yang berada di atas $75 \%$ maka menunjukkan kondisi kesehatan Bank Papua berada pada predikat sehat. LDR yang semakin kecil menunjukkan semakin tinggi tingkat nilai likuiditas bank yang disebabkan jumlah dana masyarakat yang disalurkan ke kredit mampu mencukupi.

\section{b. Faktor Earning (Rentabilitas)}

\section{1) Return On Assets (ROA)}

Return On Assets (ROA) merupakan kemampuan bank dalam menghasilkan laba atau keuntungan dengan cara mengoptimalkan penggunaan aset yang dimiliki atau yang tersedia. Berdasarkan hasil penelitian menunjukkan nilai rata-rata ROA Bank Papua periode 2011-2018 adalah sebesar 1,67\%. ROA terbesar terdapat di tahun 2011 dan 2013 yaitu sebesar 2,86\%. ROA terendah terletak di tahun 2016 yaitu sebesar $-0,61 \%$. Jika dilihat berdasar pada nilai rataratanya, maka ROA Bank Papua menggambarkan kondisi kesehatan Bank Papua berada pada predikat sehat. Semakin tinggi jumlah nilai ROA, maka rentabilitas bank akan semakin mencukupi. Hal ini sesuai dengan hasil dari penelitian yang dilakukan oleh Alizatul Fadhila dkk., dengan hasil penelitian yaitu besar rata-rata ROA bank milik pemerintah pusat berada di atas $1,25 \%$ yang menandakan kondisi ini sangat baik.

2) Net Interest Margin (NIM)

NIM merupakan rasio profitabilitas yang mengukur kinerja suatu bank. Penelitian ini menggunakan perhitungan hasil pendapatan bunga bersih dibagi dengan total aktiva produktif yang dinilai dari total aset. Berdasarkan hasil penelitian pada tabel 4.7 dapat dilihat bahwa besar nilai rata-rata NIM Bank Papua adalah sebesar $7,13 \%$. Dengan nilai tersebut maka kondisi kesehatan bank Papua berada pada predikat sangat sehat. NIM tertinggi terletak pada tahun 2013 sebesar 7,88\% dan NIM terendah terletak pada tahun 2012 sebesar 5,71\%.

Hal tersebut sejalan dengan penelitian yang dilakukan oleh Dea Amelia Suhartono dkk. yang berjudul "Analisis Tingkat Kesehatan Bank Dengan Menggunakan Metode Risk Based Bank Rating (RBBR). Hasil penelitian menunjukkan keseluruhan nilai NIM dari keempat bank untuk periode 20122015 memiliki kinerja yang sehat karena berdasarkan kategori NIM didapatkan 
nilai di atas 5\% untuk masing-masing bank, yang mana dalam hal ini maka semakin tinggi nilai NIM maka semakin sehat kinerja bank dalam satu periode.

3) Faktor Permodalan

(1) Capital Adequency Ratio (CAR)

CAR adalah rasio yang menghitung mengenai kecukupan pemodalan dan pengelolaan permodalan. Berdasarkan hasil penelitian besar nilai rata-rata CAR Bank Papua periode 2011-2018 adalah 20,32\%. CAR dengan nilai terbesar terlatak pada tahun 2011 yaitu sebesar 26,77 dan nilai CAR terendah terletak pada tahun 2014 sebesar 16,28\%.

Hal ini menunjukkan bahwa nilai CAR tersebut menempatkan kondisi kesehatan Bank Papua pada predikat sangat sehat. Semakin tinggi nilai CAR pada bank maka semakin sehat kondisi permodalan pada bank. Hasil dari penelitian ini memiliki arah yang sama dengan hasil penelitian yang dilakukan oleh Alizatul Fadhila dkk. dengan hasil penelitian menyatakan bahwa bank milik pemerintah pusat secara keseluruhan mendapat nilai CAR di atas $8 \%$ yang berarti seluruh bank milik pemerintah pusat tersebut mampu untuk memenuhi kecukupan permodalan.

2. Performa Bank Papua Berdasarkan Indikator NPL, LDR, ROA, NIM, dan CAR

a. Indikator Non Performing Loan (NPL)

Berdasarkan hasil penelitian, nilai rata-rata NPL Bank Papua periode 20112018 adalah sebesar 7,15\%. Hal ini menunjukkan bahwa dengan nilai tersebut menandakan performa Bank Papua berada pada kategori cukup baik sebab nilai rata-rata NPL berada di atas 5\%. Pada periode 2011-2018 Bank Papua mengalami sedikit kredit bermasalah. Dari penjelasan di atas maka dapat disimpulkan bahwa Bank Papua memiliki kondisi kesehatan yang cukup baik, dimana yang menjadi dasar untuk tolok ukurnya yaitu nilai rata-rata NPL yang berada pada nilai di bawah $8 \%$. Semakin rendah nilai NPL pada suatu bank maka semakin baik performa bank tersebut.

b. Indikator Loan to Deposit Ratio (LDR)

Berdasarkan pada hasil penelitian, hasil nilai rata-rata LDR Bank Papua yaitu 76,56\%. Dengan nilai tersebut, menunjukkan bahwa keadaan performa Bank Papua berada pada kategori baik. Hal ini didasarkan atas besarnya nilai rata-rata LDR Bank Papua yang berada di bawah $85 \%$. Nilai LDR tersebut menandakan bahwa Bank Papua memiliki tingkat nilai likuiditas memadai yang mana digunakan untuk menutup kewajibannya terhadap nasabah.

c. Indikator Return On Assets (ROA)

Dilihat dari hasil penelitian, hasil nilai rata-rata ROA Bank Papua periode tahun 2011-2018 adalah sebesar 1,67\%. Nilai tersebut menandakan keadaan peforma Bank Papua berada pada kategori baik karena berada di atas nilai 1,25\%.

d. Indikator Net Interest Margin (NIM)

Berdasarkan hasil penelitian ini, jumlah nilai rata-rata NIM Bank Papua periode 2011-2018 sebesar 7,13\%. Dari nilai tersebut menunjukkan bahwa berdasarkan nilai NIM keadaan performa Bank Papua berada pada kategori 
sangat baik. Hal ini menandakan bahwa selama periode tahun 2011-2018 kinerja Bank Papua adalah kinerja yang sehat.

e. Indikator Capital Adequency Ratio (CAR)

Hasil penelitian yang menunjukkan nilai rata-rata CAR Bank Papua periode 2011-2018 adalah 20,32\%. Berdasarkan hasil tersebut, maka menunjukkan bahwa keadaan performa Bank Papua berada pada kategori sangat baik yang mana hal ini didasarkan pada nilai rata-rata CAR yang berada di atas $12 \%$. Dengan nilai CAR tersebut maka menandakan kecukupan dan pengelolaan permodalan pada Bank Papua adalah sehat.

\section{KESIMPULAN DAN SARAN \\ Kesimpulan}

1. Analisis tingkat kesehatan Bank Papua menggunakan metode Risk Based Bank Rating (RBBR) melalui rasio NPL, LDR, ROA, NIM dan CAR maka kondisi tingkat kesehatan Bank Papua yaitu dapat dikategorikan berada pada predikat Sehat. Namun demikian, perkembangan nilai-nilai rasio pada Bank Papua periode 2011-2018 setiap tahunnya bergerak secara fluktuatif yang berarti perkembangannya naik turun dan pada tahun-tahun tertentu bisa mencapai angka yang kurang baik atau melebihi batas minimum nilai dari masing-masing rasio. Pada periode 2011-2018 berdasarkan lima indikator dari metode RBBR maka tahun yang memiliki predikat paling sehat terletak pada tahun 2011-2013 karena kelima indikatornya berpredikat sangat sehat.

2. Peningkatan perkembangan Bank Papua periode 2011-2018 berdasarkan indikator NPL, LDR, ROA, NIM dan CAR bergerak secara fluktuatif dan pada tahun tertentu memiliki nilai yang tidak memenuhi standar minimum kesehatan bank. Namun demikian, maka dapat disimpulkan bahwa performa Bank Papua dikategorikan baik.

\section{Saran}

1. Bagi Nasabah dan Investor

Nasabah harus cermat dalam menentukan keputusan mereka dalam memilih bank, dengan memilih bank yang sehat diharapkan nasabah dapat mengantisipasi risiko-risiko yang sering dihadapi bank. Sehingga nasabah dapat mempercayakan dana mereka dengan aman. Begitu pula dengan investor harus lebih cermat dalam menentukan keputusan mereka atas investasi yang dijalankannya untuk menghindari kerugian dalam memilih bank yang sehat. Dengan memilih bank yang sehat diharapkan dana yang diinvestasikan digunakan dengan baik.

2. Bagi Manajemen Bank

Manajemen bank disarankan agar semakin baik dalam membenahi tingkat kualitas kinerjanya sehingga memperoleh predikat sangat sehat. Dengan demikian hal tersebut akan menjadi salah satu alasan terbesar para investor dan nasabah untuk memilih tempat yang tepat dalam menanamkan dananya.

3. Bagi Akademisi

Bagi akademisi diharapkan penelitian ini menjadi bahan referensi untuk pembelajaran dalam menilai kesehatan bank dan pengembangan ilmu. 


\section{Bagi Peneliti selanjutnya}

Bagi peneliti yang berikutnya, akan lebih baik agar memperbesar cakupan peneliti mengenai penilaian tingkat kesehatan bank dengan menggunakan indikator lain perhitungan rasio keuangan pada pengukuran tingkat kesehatan bank berdasarkan metode yang digunakan sesuai dengan yang dijelaskan dalam Surat Edaran Bank Indonesia.

\section{DAFTAR REFERENSI}

Amelia, Erika, Astii Chandra Aprilianti. (2018), "Penilaian Tingkat Kesehatan Bank: Pendekatan Camel dan RGEC”, Jurnal Akuntansi Dan Keuangan Islam No.2/ Oktober

Armanto, Boedi (Deputi Komisioner Pengawas Perbankan I OJK). (2020). Kontan.co.id diakses pada tanggal 21 Januari 2020.

Dyah A., Nindyani, Achmad Husaini, Devi Farah Azizah. (2012), “Analisis Tingkat Kesehatan Bank

Dengan Menggunakan Metode Camel: Studi Pada PT. Bank Jatim, Tbk Malang Periode 2010-2012”. Ikatan Bankir Indonesia (IBI). (2018), Memahami Audit Intern Bank Edisi ke-1 Cet. Ke-3. Jakarta : PT Gramedia Pustaka Utama.

Kasmir. (2008) Bank dan Lembaga Keuangan Lainnya, Edisi Revisi 2008. Jakarta : PT. Raja Grafindo Persada,.

Kuras Purba. (2019), Manajemen Perbankan Cet. Ke-1. Bandung : Yrama Widya. Lampiran Surat Edaran BI 13/24/DPNP/2011

Lopes Costa , Fabio Maria. (2020), "Kredit Bermasalah di Bank Papua Mencapai Rp 1,5 Triliun”. Kompas.com diakses pada 21Januari 2020.

Luthfiani, Rini Rahayu Kurniati, dan Daris Zunaida. (2016), “Analisis Tingkat Likuiditas Bank Terhadap Kesehatan Bank: Studi Kasus Pada Bank BNI".

Peraturan Bank Indonesia Nomor 6/10/PBI Tahun 2004 tentang Tingkat Kesehatan Bank Pasal 1.

Peraturan Bank Indonesia No. 13/1/PBI/2011 Tentang Penilaian Tingkat Kesehatan Bank Umum.

Peraturan Otoritas Jasa Keuangan Nomor 4/POJK.03/2016 Tentang Penilaian Tingkat Kesehatan Bank Umum Pasal 6 dan Pasal 7-8.

Rustendi, Tedi. (2011), “ Analisis Kesehatan Bank Berdasarkan Kecukupan Modal, Kualitas Aktiva Produktif, Manajemen, Rentabilitas, dan Likuiditas: Studi pada BPR Siliwangi, Tasikmalaya”, Vol. 6 No. $1 /$ Juni.

Suhartono, Dea Amelia, Zahroh ZA, Devi Farah Azizah,. (2017), “Analisis Tingkat Kesehatan Bank Dengan Menggunakan Metode Risk Based Bank Rating: Studi pada Bank Milik Pemerintah Pusat yang Terdaftar di Bursa Efek IndonesiaTahun 2012-2015”, No.1/Mei.

Totok, Budisantoso dan Triandaru Sigit. (2006), Bank dan Lembaga Keuangan Lain. Jakarta : Salemba Empat. 